\title{
LITERATUROZNAWSTWO
}

\author{
JOLANTA BRZYKCY
}

\section{Świat jako tranzyt. Poetyka przestrzeni w poezji Gizelli Lachman}

\author{
The world as a transit. The poetics of space \\ in the poetry of Gisella Lachman
}

\begin{abstract}
The article is an analysis of the poetry of Gisella Lachman (1895-1969), poet of the "first wave" of Russian emigration, from the perspective of the poetics of space. The poet expressed her emigration experience (multiple changes of residence: Russia, Germany, Switzerland, USA) in her poems in spatial relations. They appear on different levels of the works' morphology: in the construction of the lyrical "I", in the organisation of the presented world, in the repertoire of motifs and the selection of poetic lexis and genre forms. Space plays a literal role in Lachman's poetry; it is a representation of extra-literary reality, seen subjectively. It is also subject to metaphorisation, becoming a tool for expressing philosophical content. The poet creates not only a spatial model of the world, but also a spatial model of human life, which she perceives as a transit on the road to eternity.
\end{abstract}

Keywords: Gisella Lachman, first wave of Russian emigration, poetry of White emigration, poetics of space, spatial model of human life

Jolanta Brzykcy, Uniwersytet Mikołaja Kopernika w Toruniu, Toruń - Polska, tomine@umk.pl, ORCID ID: https://orcid.org/0000-0001-9563-0723

Przestrzeń i emigracja pozostają ze sobą w szczególnie bliskich, wręcz nierozerwalnych relacjach. Emigracja, oznaczająca wyjazd z ojczystego kraju do innego państwa, stały lub okresowy pobyt w innym państwie (Słownik języka polskiego), wiąże się z dobrowolnym lub przymusowym przemieszczeniem w przestrzeni fizycznej, geograficznej i kulturowej, jest opuszczeniem „swojego miejsca” na ziemi i wyruszeniem w inną przestrzeń, często nieznaną i obcą. Czynność emigrowania i sytuacja bycia na emigracji oznacza zmienione położenie w świecie, dyslokację w planie geograficznym i kulturowym, 
przejście w inne pole semantyczne i inny system wartości. Pisząc o tych zagadnieniach, emigranci i badacze wskazują na takie aspekty, jak: opuszczenie (domu, bliskich, narodu, czytelników), dystans fizyczny, rozziew przestrzenny (Dobieszewski 33), znalezienie się na zewnątrz, przesunięcie poza centrum, wyjście „poza”, przekroczenie granic (politycznych, kulturowych, językowych, psychologicznych). W zależności od przyczyn emigracja bywa utożsamiana z podróżą, wędrówką, pielgrzymką lub ucieczką, tułaczką, wygnaniem (banicją). Niektórzy badacze, mając na uwadze jednokierunkowość emigracji, wpisaną w nią niemożność powrotu do porzuconych miejsc, proponują postrzeganie jej jako antypodróży, podróży zredukowanej, nieukończonej (zob. Time). Wspólnym mianownikiem wszystkich tych określeń i asocjacji są wyobrażenia przestrzenne, u podstaw których leży ruch i wiążące się z nim przesunięcie terytorialne.

Emigracja prowokuje także specyficzne postrzeganie przestrzeni, wprowadza do niej nieodwracalne pęknięcie na dwie strefy, zazwyczaj odmiennie waloryzowane i nacechowane: ojczyznę i obczyznę (Wyskiel 37; Ndiaye 2008: 132). Pisał o tym Czesław Miłosz:

Wyobraźnia, zawsze przestrzenna, wskazuje na północ, południe, wschód i zachód od pewnego centralnego, uprzywilejowanego miejsca, którym jest przypuszczalnie wioska naszego dzieciństwa czy nasz powiat. Jak długo pisarz mieszka w swoim kraju, uprzywilejowane miejsce, koliście się rozszerzając, utożsamia się z całym krajem. Wygnanie przesuwa ten ośrodek; a raczej tworzy dwa ośrodki. Wyobraźnia odnosi wszystko do otoczenia „tam, daleko” [...].

Wyobraźnia kierująca się ku odległemu regionowi czyjegoś dzieciństwa jest typowa dla literatury tęsknoty [...]. Chociaż dość rozpowszechniona, literatura tęsknoty jest tylko jednym z wariantów radzenia sobie z oderwaniem od rodzinnego kraju. Nowy punkt, który organizuje przestrzeń w odniesieniu do siebie, nie może zostać wyeliminowany, to znaczy nie można siebie wyabstrahować z fizycznej obecności w określonym miejscu na Ziemi. Dlatego właśnie powstaje dziwne zjawisko: dwa ośrodki i dwie przestrzenie stworzone wokół nich nakładają się na siebie lub - i to jest szczęśliwe rozwiązanie - zrastają się w jedno (Miłosz, źródło elektroniczne).

Wszystkie te, nakreślone w dużym skrócie, przestrzenne konotacje emigracji znalazły wielokrotne i bogate pod względem form wyrazu artystycznego odzwierciedlenie w twórczości literackiej emigrantów rosyjskich ,pierwszej fali”. Dla zilustrowania zagadnienia zacytuję wiersz Aleksieja Aczaira (właść. nazwisko Gryzow) По странам рассеяния. Doskonale oddaje on wysoki współczynnik geograficzny, jakim cechuje się poezja ,pierwszej fali”:

Мы живали в суровой неметчине,

Нам знакомы Алжир и Сиам;

Мы ходили по дикой Туретчине

И по льдистым небесным горам. 
Нам близки и Памир, и Америка,

И Багдад, и Лионский залив.

Наш казак у восточного берега

Упирался в Дежневский пролив. [...]

На плантациях, фермах, на фабриках, где ни встать, ни согнуться, ни лечь, в аргентинах, канадах и африках раздается московская речь. [...]

Не сломила судьба нас, не выгнула, хоть пригнула до самой земли... А за то, что нас Родина выгнала, мы по свету ее разнесли. (Russkaâ poèziâ Kitaâ, źródło elektroniczne)

W tłumie rosyjskich uchodźców, wygnanych z Rosji i roznoszących ją po świecie, znalazła się Gizella Lachman - poetka już za życia działająca w cieniu wielkich sław „białej emigracji”, dziś zaś właściwie nieznana i niedostrzegana przez historyków literatury rosyjskiej ${ }^{1}$. Aby tę anonimowość przełamać, przytoczę fragment notki biograficznej:

[...] poetka i tłumaczka urodziła się w 1895 roku w Kijowie. Szczęśliwe dni dzieciństwa i wczesnej młodości na Ukrainie, w majątku rodziców, określiły pogodną tonację jej poezji. Wykształcenie zdobyła w Kijowie. W 1919 roku, mając 24 lata, wyemigrowała do Niemiec. Mieszkała w Berlinie, gdy istniała tam duża kolonia pisarzy rosyjskich. Jednakże jej własne pierwsze próby poetyckie nie wyszły poza poziom dyletanctwa; świadoma tego, na długo zarzuciła poezję.

W drugiej połowie lat 20. przeniosła się na stałe do Szwajcarii. Wybuch II wojny światowej zmusił ją do nowej emigracji, jesienią 1940 roku wyjechała do Lizbony, skąd statkiem - do USA.

Od 1941 roku Lachman mieszkała w Nowym Jorku. W 1943 roku, nieoczekiwanie dla samej siebie, zaczęła pisać wiersze. Jej debiut literacki miał miejsce w czasopiśmie „Новое русское слово” ш 1944 roku. Mieszkając w Nowym Jorku, zbliżyła się do uczestników „Kółka rosyjskich poetów w Ameryce" [...]. W 1949 roku wspólnie z J. Antonową, J. Markową, K. Sławiną, T. Timaszową, Z. Trocką i innymi członkami kółka wydała almanach Четырнадиать, którego tytuł oznaczał liczbę autorów.

W latach 50. jej wiersze i przekłady były publikowane w czasopismach „Мосты”, „Новый журнал”, „Новое русское слово” і innych emigracyjnych periodykach. Dwa tomiki poetyckie, Пленные слова (1952) і Зеркала (1965), zawierają sto wierszy i kilka przekładów z Emily

${ }^{1}$ Pojedyncze wiersze Lachman, wraz z biogramami, zostały włączone do kilku antologii rosyjskiej poezji emigracyjnej (Kovaldži 98-106, 425-426; Krejd 1995: 287-288, 635-636). W Polsce jej twórczość i sylwetkę przybliżyła Iwona Anna Ndiaye (Ndiaye 2006: 195-199, 393). Zob. także Aleksandrov 299. Wiersze Lachman wydano na Ukrainie w 1997 roku. Tomik został opatrzony dwoma wstępami: Jurija Koczubeja (Kočubej) i Oleksandra Fiedoruka (Fedoruk). Obszerny szkic o poetce opublikował kilkanaście lat temu Jurij Lewing (Leving). Są to, jak dotąd, jedyne opracowania poezji Lachman. 
Dickinson, Roberta Frosta i Edny St. Vincent Millay. W 1966 roku kilka jej wierszy włączono do antologii Содружество.

[...] zmarła w 1969 roku w USA [przekład mój J.B]. (Krejd 2001).

Rekonstruując biografię Lachman, jej autor siłą rzeczy uwypuklił stygmat wygnańczego niezakorzenienia i wiążący się z nim aspekt przestrzenny. Kilkukrotne zmiany miejsca zamieszkania, wymuszone przez sytuację polityczną lub bardziej prozaiczne, ale przecież ważne, powody finansowe (w poszukiwaniu pracy poetka przeniosła się z Nowego Jorku do Waszyngtonu²), sprawiły, że indywidualne doświadczenie wygnania wpisuje się w kulturową parabolę emigracyjnej eksterytorialności.

W poezji Lachman zagadnienia te znalazły odzwierciedlenie przede wszystkim w relacjach przestrzennych. Ujawniają się one na różnych poziomach morfologii utworów poetki: w konstrukcji ,ja” lirycznego, w organizacji świata przedstawionego, w repertuarze motywów i sprzężonym z nim doborze określonej leksyki poetyckiej oraz form gatunkowych ${ }^{3}$. Ich analiza jest celem niniejszego artykułu.

Podmiot wierszy Lachman znajduje się na ogół w ruchu: spaceruje, odbywa krótkie samochodowe przejażdżki, piesze wędrówki czy międzykontynentalne podróże. Motywacja tych przemieszczeń jest różna, dyktowana wewnętrzną potrzebą bądź narzucona przez zewnętrzne okoliczności, niezależna od woli podmiotu. W pierwszym przypadku są to przechadzki lub górskie wycieczki z ukochanym, opisywane w wierszach o tematyce miłosnej:

\footnotetext{
Нас ангелы оберегали,

Когда встречались мы с тобой

И рядом шли, забыв печали,

На миг обласканы судьбой.

Мы в очарованной долине

Бродили вдоль каких-то рек... [...]

[...] Меж гладкой скалой и глубоким оврагом

Тропинка была так узка.

По ней ты спускался уверенным шагом,

Ты мне улыбался слегка... [...] (Lahman) ${ }^{4}$
}

2 Według niektórych biogramów (http://www.vekperevoda.com/1887/lahman.htm) poetka mieszkała też w Filadelfii.

${ }^{3}$ Przestrzeń artystyczną w poezji Lachman rozumiem, za Jurijem Łotmanem, jako „continuum, w którym rozmieszczone są postaci i toczy się akcja”. Można je, do pewnego stopnia, identyfikować z przestrzenią fizyczną, choć należy pamiętać o prymarnej funkcji „,modelowania stosunków pozaprzestrzennych" (Łotman 220).

${ }^{4}$ Wszystkie wiersze cytowane są według wydania: Gizela Lahman, Vibrani poezii/Gizella Sigizmundovna Lahman. Izbrannaâ poèziâ. Kiev, Triumf, 1997. Web. 29.09.2020. http://ju.org.ua/ru/ literature/749.html. 
oraz przemieszczenia o znacznie większym zasięgu terytorialnym, jak eskapada po Europie, będąca kompozycyjną i fabularną kanwą cyklu wierszy Notatnik podróżny (Путевая тетрадь). Przeciwwagę dla ruchliwości waloryzowanej pozytywnie, gdyż inicjowanej przez sam podmiot, świadomej i dobrowolnej, stanowią jej odmiany przymusowe, jak emigracyjna tułaczka lub podróże mentalne, mimowolne, bo odbywające się we śnie lub nagłym wspomnieniu. Pierwsze z nazwanych „przemieszczeń negatywnych” rzadko jest wyrażane wprost, jedynie w dwóch wierszach przybiera eksplicytną postać („Куда ведут скитальческие тропы?”, „За море-океан в изгнанье принесла / Степного ветра гул и плач метели снежной”). Motyw onirycznej podróży w przeszłość, spotkania z dawno niewidzianymi czy też nieżyjącymi już bliskimi bądź z samą sobą sprzed lat pojawia się u Lachman częściej (zob. wiersze: Странниц̧а, Все в мире круто изменилось..., Зеркала). Strategie kommemoratywne są wówczas sprzężone z czynnością pokonywania przestrzeni (i czasu), co znajduje wyraz w zastosowaniu odpowiednich czasowników ruchu:

\footnotetext{
Хочу помчаться невидимкой

На крыльях радостного сна

Туда, где за прозрачной дымкой

Лежит далекая страна. [...]

Взберусь, как странница с котомкой,

На деревянное крыльцо [...].
}

Nieodłącznym rezultatem przemieszczeń ,ja” lirycznego w przestrzeni fizycznej, geograficznej i kulturowej jest jej dyferencjacja. Skorelowana z ruchem zmiana percepcji wprowadza do otoczenia napięcia i pęknięcia, zarysowuje w nim linie podziału, prowadzi do różnicowania według rozmaitych kryteriów. Zasadnicze w tym względzie są opozycje przestrzeni otwartej i zamkniętej (pole, równina, ulica - dom, pokój, numer hotelowy), przynależnej do świata natury i kultury (góry - miasto), prywatnej i publicznej (dom - dworzec), zorientowanej wokół osi pionowej (ziemia - niebo) i horyzontalnej (blisko - daleko, tu - tam).

Jednym z istotnych, choć wcale nie prymarnych uporządkowań przestrzeni w świecie przedstawionym wierszy Lachman jest, będący pochodną emigracyjnej eksterytorialności, rozłam na ojczyznę i obczyznę. Zgodnie z regułami, jakie rządzą literaturą emigracyjną (por. Wittlin), przestrzeń ojczysta ukazywana jest przez poetkę jako odległa w płaszczyźnie spacjalnej i temporalnej, bezpowrotnie utracona („Мой край незабытый и дальний”, „до сих пор нам снится / Примерещившаяся страна"), szczególnie droga podmiotowi, wyposażona wyłącznie w pozytywne konotacje (poczucie bezpieczeństwa, brak trosk, szczęśliwe dzieciństwo, miłość, bliskość innych). Jej reprezentantami są matryce wyobrażeniowe ukraińskiego pejzażu, z typowym dla niego bezkresem i sennością urodzajnej, żyznej równiny: 
[...] Плывут во всем великолепьи

Растрепанные ветром степи,

В цвету вишневые сады,

Как будто бы в пушинках снега.

Плетется и скрипит телега;

Колес глубокие следы

Видны на вязком черноземе;

Ее везут в ленивой дреме,

Шагая с важностью, волы [...].

Ten krajobraz bywa niekiedy uzupełniany o znaczące atrybuty kulturoznawcze:

[...] Звон бубенцов, песнь ямщика

И гул Днепра слились в просторе [...].

Kreując obrazy kraju ojczystego, poetka sięga także - choć czyni to rzadko - po toponimy. Jest to przede wszystkim Dniepr („над синеющим Днепром / Вьется дым веселый парохода”, „Ты принес мне издалека кусочек России - / Колокольные звоны и омут Днепра") i charakterystyczne dla topografii Kijowa (którego nazwa w wierszach się nie pojawia), choć mniej rozpoznawalne, punkty: Mogiła św. Askolda, czyli uroczysko z cmentarzem, położone na prawym, wysokim brzegu Dniepru i most Łańcuchowy przerzucony przez rzekę w pobliżu Mogiły, w 1853 roku, nazywany także Mikołajewskim, na cześć ówczesnego cara Rosji. Oba elementy architektury rodzinnego miasta Lachman wprowadziła do wiersza Майский ветер, штору шевеля...:

\section{[...] Над обрывом меж плакучих ив \\ Расцветает снова куст сирени. \\ Девочка читает, положив \\ Мраморную книгу на колени. \\ Неподвижны в мраморных руках \\ Широко раскрытые страницы. \\ Видишь, легкой стайкой в облаках \\ За Цепным мостом летают птицы. \\ Запах мая в воздухе разлит... \\ Мы с тобой о смерти там забыли, \\ Где трава росла меж древних плит \\ На Аскольдовой могиле.}

Warto dodać, że utwór powstał w 1949 roku, gdy nie istniał już ani cmentarz, zamknięty przez bolszewików w 1919 roku i zamieniony na park miejski, ani most, zburzony rok później. Nie wiadomo, czy fakty te były znane poetce, jednak niezależnie od tego wzmagają one wyrażone w wierszu poczucie bezpowrotności przeszłości. 
Ważnym komponentem kreowanej w omawianych wierszach przestrzeni ojczystej, co także odpowiada fizjologii literatury emigracyjnej, jest dom rodzinny. Podobnie jak i pozostałe komponenty fizycznie nieosiągalnej ojczyzny, jest on dostępny jedynie w snach i wspomnieniach podmiotu lirycznego; niekiedy - jak w wierszu Возвращение домой - urzeczywistnia się w poetyckim akcie twórczym:

\footnotetext{
Зачем писать о том, что только снится,

Чего давно на свете больше нет?

Но лист покрыли черные изломы,

Слова колдуют и поют в ночи -

В развалинах разрушенного дома

Зашевелились тихо кирпичи.
}

Symbolika domu w wierszach Lachman również mieści się w paradygmacie emigracyjnych wyobrażeń przestrzennych, nakazujących widzieć w nim centrum wszechświata, gniazdo rodzinne, azyl, siedzibę rodu, więź z przeszłością, trwałość, ostoję itp. Poetka, kreśląc obrazy przytulnej sypialni („в детстве мне казалась веселее / Она всех комнат на земле") bądź też wspominając odczuwaną w dzieciństwie beztroskę („Взбегаю быстро на крыльцо, / Смеюсь, как девочка, беспечно"), jawnie odwołuje się do tych znaczeń. Pieczołowitość, z jaką rekonstruuje wnętrze domu i jego najbliższe otoczenie, jest miarą jej tęsknoty za utraconym rajem na ziemi:

[...] Обнявши стену цепкими руками,

Тянулся плющ и вился у окна.

А на окне вздохнули занавески [...]

На старой люстре вспыхнули подвески

И улыбнулся бабушкин портрет.

[...] Дома были синие обои,

Столик под кисейною волной,

Зеркало в серебряной оправе... [...]

Раскрыты широко ворота.

Как встарь, два дуба у ворот

Кивают ласково листвою. [...]

Zgodnie z prawami emigracyjnej optyki naturalnym dopełnieniem, a zarazem przeciwnym biegunem dla przestrzeni ojczyzny jest obczyzna. Lachman podporządkowuje się tej zasadzie jedynie częściowo. Po pierwsze, dychotomia ta nie jest kluczowa w jej poezji, czytelne ślady pęknięcia na przestrzeń „obcą” i „swoją" znaleźć można w kilku zaledwie wierszach. Odnotujmy, gwoli badawczej rzetelności, że osią jednego z nich jest nieprzystawalność obu sfer: 
На чужбине и солнце, и тучи другие,

И волна говорит на чужом языке...

Я черчу твое имя, Россия,

На приморском песке [...],

z kolei ideową kanwę drugiego utworu stanowi emigracyjna bezdomność, unaoczniona w obrazie hotelowego pokoju. Podmiot liryczny wiersza to uchodźca, który bezskutecznie próbuje przekształcić bezosobowe wnętrze wynajętego numeru we własne miejsce na ziemi:

За неделей тихо тянется неделя,

И, быть может, годы мирно здесь пройдут.

В комнате безличной, в комнате отеля

Я создать стараюсь свой былой уют.

Разложила книги, вынула портреты

И накрыла пледом старенький сундук

С новою надеждой, с песней недопетой

О конце скитаний, о конце разлук.

Равнодушны стены, но смеются вещи,

Вылез из-под пледа красочный ярлык.

Музы Дальних Странствий слышу голос вещий...

У вещей лукавых свой живой язык.

Jednak, ogólnie rzecz biorąc, zbyt rzadko Lachman mówi o wygnaniu, by można było uznać, że temat ten szczególnie ją frapuje. Co więcej, w niektórych przypadkach deszyfracja wygnańczego kodu jest właściwie niemożliwa bez znajomości biografii poetki. Do wierszy, które można określić mianem autobiograficznych, należą np. Нью-йоркская ночь... Небоскребы... і Когда-нибудь мь встретимся опять... W obu ideową i kompozycyjną zasadą jest kontaminacja dwóch typów przestrzeni: obiektywną przestrzeń obczyzny przenika oniryczna przestrzeń kraju rodzinnego:

Нью-йоркская ночь... Небоскребы

Окутала снежная мгла...

Мерещатся где-то сугробы,

По белым холмам - купола,

Овраги, глухие дороги

И тонкая ткань серебра,

Что кинул волшебник двурогий

На синие льдины Днепра....

[...] Ржаное поле, свежие снопы

Мелькнут на месте небоскреба.

Почудятся в осенней полумгле 
Под фонарями улицы дождливой

Следы копыт на взрыхленной земле

И дом с колоннами за нивой. [...]

O tym, że przebitka dwóch planów czasoprzestrzennych wyrasta z osobistych wygnańczych doświadczeń autorki, nie sposób dowiedzieć się z tekstu wiersza, do jego odczytania w tym właśnie kluczu konieczna staje się wiedza o jego pozaliterackich kontekstach ${ }^{5}$.

Inna przyczyna, dla której rzeczywistość artystyczna Lachman wymyka się emigracyjnym typologiom przestrzennym, tkwi w odmiennej od powszechnie przyjętej wśród rosyjskich poetów ,,pierwszej fali” waloryzacji obczyzny. W odróżnieniu od wielu swoich pobratymców, dla których wszystko, co usytuowane poza Rosją, jest obce, inne i niechciane ${ }^{6}$, poetka wzbrania się przed jednoznacznie negatywnym osądem zagranicy. Świadczy o tym, do pewnego stopnia, bogaty repertuar rekonstruowanych przez nią krajobrazów obczyzny. Weduty Nowego Jorku i europejskich metropolii (Kolonia, Paryż, Wenecja, Bazylea, Stambuł), szkice włoskich i francuskich zabytków architektury (katedra w Chartres, Droga Appijska), pejzaże Alp, południowych Włoch czy tureckich płaskowyżów są dowodem zainteresowania poetki nieznanym i dlatego właśnie wartym poznania otoczeniem. Lachman cechuje otwarcie na kulturę kraju osiedlenia, nie daje się ona sprowokować do typowo wygnańczych porównań i hierarchizacji, unika kulturowej konfrontacji przebiegającej wzdłuż osi metropolia - diaspora. Jej europejskie pejzaże są utrzymane w tonie notatek z podróży, sporządzanych nie przez zmagającego się z traumą wygnania Rosjanina, lecz przez wytrawnego podróżnika. To obywatel świata, obdarzony subtelnym smakiem i zmysłem obser-

${ }^{5}$ Trudno jednoznacznie rozstrzygnąć kwestię autobiografizmu poezji Lachman. Z jednej strony zbyt mało wiemy o jej życiu, by w rzeczywistości artystycznej dostrzegać refleksy weryzmu, należy też ostrożnie podchodzić do formuły „życia i twórczości”, pamiętając, że może ona pomniejszać rangę autonomiczności procesów twórczych, pomijać dążenie pisarza do rozgrywania swego życia jako spektaklu, w którym są stosowane określone strategie twórcze (Wyskiel 9-10). Z drugiej strony badacze wskazują, że „w rosyjskiej poezji emigracyjnej uwidacznia się owo szczególne pojmowanie twórczości, zgodnie z którym między życiem a sztuką w ogóle (głównie zaś literaturą) zachodzi swoista relacja: dzieło i twórca nie występują w izolacji czy dychotomicznym antagonizmie. Przeciwnie - dzieło stanowi niejako transpozycję sytuacji życiowej artysty" (NDiaye 2008: 116). Tendencje autobiograficzne mogą mieć wręcz znaczenie terapeutyczne dla samego twórcy: „Писатель-эмигрант, лишенный корней и вынужденный приспосабливаться к их отсутствию, рассматривает писание не только как возможность формирования жизненного пространства, но и как возможность авторефлексии и конструирования или реконструирования «я» после пережитой травмы эмиграции" (Bugaeva 64).

${ }^{6}$ Por. na przykład wypowiedź Piotra Wajla i Aleksandra Genisa: „Горечь нашего положения как раз и заключается в том, что мы подвешены в безвоздушном пространстве" (суt. za: Ndiaye 2008: 113). 
wacji, pozbawiony kompleksów, ale i zdolny do krytycznego osądu. Znakomity przykład takiej optyki stanowią obrazy Stambułu i Wenecji (z wierszy Прогулка nо Босфоре і Венеция). Oba miasta wywołują wyraźne zaciekawienie podmiotu, jego dezaprobatę budzi zaś nie ich odmienność kulturowa, lecz merkantylizacja. Obliczone na większy zysk innowacje, w rodzaju wznoszonych naprędce hoteli, dawnych pałaców przekształcanych w muzea czy hałaśliwych udogodnień w transporcie miejskim, niszczą żywą tkankę miasta i naruszają ich wielowiekową aurę. Podmiot ubolewa nad tym, że dawne pałace - siedziby haremów, opiewane m.in. przez Puszkina, zostały zamienione na placówkę naukową, a weneckie gondole są wypierane przez tramwaje wodne. Oba wiersze Lachman można uznać za poetycki sprzeciw wobec XX-wiecznego rozwoju masowej turystyki jako ruchu kształtującego współczesny krajobraz kulturowy:

\author{
[...] Крепость Магомета, старый храм, \\ И дворец, где - может быть - в гареме \\ Привиденья до сих пор живут, \\ Бродят сестры пушкинской Заремы... \\ Там теперь научный институт. \\ Гордую мечеть давно успели \\ Превратить в музей; а к тем дворцам \\ Делают пристройки для отелей \\ По американским образцам.... [...]. \\ [...] Над лагунами не слышен, \\ Как встарь, пленительный напев. \\ К прекрасному презренья полный, \\ Моторный катер - быстроход \\ Вздымает на каналах волны \\ Забрызганных бензином вод. \\ „Трамваи” на воде практичны. \\ Доступны всем. Им нет числа. \\ От них на город необычный \\ Тень современности легла [...].
}

Przedstawione powyżej rodzaje przestrzeni, spotykane w wierszach Lachman, wraz z wypełniającymi je artefaktami i wytworami natury mieszczą się w ramach obrazowania werystycznego, opartego na zasadzie mimetyzmu. Pejzaże kreowane przez poetkę są odwzorowaniem rzeczywistości pozaliterackiej, przepuszczonym, rzecz jasna, przez filtr jej subiektywnej świadomości.

W zainteresowaniu światem realnym badacze upatrują związek jej twórczości z estetyką akmeizmu, którego przedstawiciele głosili umiłowanie „naszej planety Ziemi” (Mandelsztam 48) i widzieli w niej jedyną inspirację dla twórcy. Istotnie, poetce obce są mistyczne poszukiwania pozaziemskich bytów, wycieczki do mitycznych i baśniowych krain, budowanych mocą własnej wyobraźni bądź 
zapożyczonych z przebogatego rezerwuaru kultur i cywilizacji świata. Jednakże podmiot jej wierszy odczuwa czasem pokusę zerwania okowów świata rzeczywistego, pragnie dowiedzieć się, co kryje się za jego namacalną stroną:

Мы все в оковах трех привычных измерений,

Но я хочу узнать, что даст грядущий час.

Стремлюсь я разглядеть незримые для нас

Пределы скрытые неведомых ступеней [...].

Przestrzeń realna dominuje w poezji Lachman, bywa jednak przeciwstawiana innym odmianom przestrzeni, nierzeczywistym, fantastycznym, niemającym odpowiednika w świecie zjawisk obiektywnych. Dwa rodzaje takich interakcji zasługują na bardziej szczegółowe omówienie. W pierwszym przypadku przeciwległym biegunem przestrzeni realnej staje się przestrzeń oniryczna. Ta opozycja uaktywnia się w wierszach, w których podmiot liryczny, pokonując opór czasu, materii i własnego ciała, przenosi się, mocą snu, marzenia lub wspomnienia, w przeszłość lub przyszłość, ku minionemu lub oczekiwanemu. Powodowane tęsknotą, pragnieniem podsumowania własnego życia lub potrzebą przewidzenia, tudzież zaplanowania jego dalszego przebiegu, ,ja” liryczne powraca albo wybiega myślą naprzód do równoległego wymiaru czasowego. O tego typu przemieszczeniach, motywowanych na ogół psychologicznie, była już mowa powyżej, warto jednak stwierdzenia te poprzeć jeszcze jednym cytatem:

[...] Но в пространстве за видимым краем,

Там, где нет ни преград, ни границ,

За пределом земных измерений

Расцветают иные пути...

И на тихой тропе сновидений

Так легко нем друг друга найти.

W drugim przypadku rzeczywistość poddająca się doświadczeniu, wraz z jej namacalnością i trójwymiarowością, jest konfrontowana ze swego rodzaju nadprzestrzenią, równie nieempiryczną i pozbawioną parametrów fizycznych, co sny i marzenia, lokowaną jednak poza samym podmiotem i niezależną od niego. Najbardziej charakterystyczny pod tym względem wydaje się wiersz Я в полудреме в вечность заглянула... ${ }^{7}$, w którym podjęta przed podmiot liryczny próba zrozu-

${ }^{7}$ Wiersz nawiązuje do utworu Tiutczewa День и ночь. Więź intertekstualna obejmuje temat obu utworów (poszukiwania egzystencjalne) oraz zastosowane dla jego zobrazowania rozwiązania artystyczne. W wierszu Tiutczewa irracjonalna osnowa świata, uosabiana przez noc, kryje się za zasłoną dnia, racjonalnego i dlatego dającego poczucie bezpieczeństwa. Zerwanie tej zasłony, równoznaczne z obnażeniem prawdziwej istoty świata, jest dla podmiotu doświadczeniem traumatycznym. W wierszu Lachman ,ja” liryczne „zagląda do wieczności”, gestem tym poetka przywołuje 
mienia istoty świata odbywa się poprzez „,zajrzenie” do wieczności, wyraźnie zobrazowanej jako inna, odrębna przestrzeń. Wywołane tą czynnością niepewność, strach, bezsilność zostały oddane za pomocą potraktowanego dosłownie idiomu: stracić grunt pod nogami (,потерять почву под ногами”):

\footnotetext{
Я в полудреме в вечность заглянула.

И, содрагаясь, отшатнулась я.

В раскатах грозных неземного гула

Еще дрожала под ногой земля

И ускользала где-то...

Свой рай грядущий, может быть, губя,

Я ухватилась за мою планету,

Ее в бессильи яростней губя.
}

Z kolei w utworze Рождение первенца wyobrażenia przestrzenne posłużyły poetce do wyrażenia koncepcji praegzystencji. Zgodnie z nią cud narodzin polega na opuszczeniu ,przed-świata”, siedziby bytów duchowych, i wejściu w wymiar ziemski, materialny i cielesny:

\section{[...] С победным возгласом вошел он в дом отцов}

Из мира смутных снов, куда нам нет возврата [...]

Oba wiersze wskazują ciekawą właściwość rzeczywistości kreowanej przez Lachman: kategorie przestrzenne są w niej wyposażane w znaczenia wtórne, stają się nośnikami innych, nieprzestrzennych sensów. Lub, by posłużyć się uwagą badacza, obok przestrzeni mówionej w jej utworach istnieje także przestrzeń mówiąca (Głowiński 81). Poetka wprzęga język relacji przestrzennych do refleksji filozoficznej. Pisząc o tajemnicy ludzkiego bytu i istnienia świata, a więc o sprawach najtrudniejszych, bo niepoznanych i niepojętych, celowo, a może instynktownie, wybiera rozwiązanie zapewniające sukces: odwołuje się do przestrzeni jako ,jednego z podstawowych parametrów naszego życia” (Wallis 43), ,zasadniczego składnika naszego świata" (Tuan 13), który wspólnie z czasem zamyka w sobie całą rzeczywistość, a warunkując pojmowanie każdej rzeczy realnej", pozwala myślowo ogarnąć kwestie wymykające się ludzkiemu doświadczeniu. Wyobrażenia przestrzenne stają się dla Lachman głównym narzędziem rozumienia rzeczywistości, pomagają nadać sens własnemu życiu. Dlatego w odniesieniu do jej wierszy mówić można nie tylko o przestrzennym modelu świata, ale i prze-

metaforę „złotej kotary dnia”. Umykająca spod stóp podmiotu ziemia jest odpowiednikiem bezdennej otchłani (бездна) Tiutczewa. W obu przypadkach to metafizyczne przeżycie budzi jednakową reakcję emocjonalną: lęk, poczucie własnej znikomości w obliczu kosmosu.

8 „Czas i przestrzeń są ramami, które zamykają w sobie całą rzeczywistość. Nie możemy pojąć żadnej rzeczy realnej inaczej, jak tylko w warunkach czasu i przestrzeni” (Cassirer 92). 
strzennym modelu bytu. Wytyczony przez narodziny i śmierć, dwa progi, jakie musi przekroczyć każdy z nas, zamknięty w granicach trzech wymiarów, jest on częścią większej, kosmicznej układanki, a jednocześnie przestrzenią tranzytową, poczekalnią $\mathrm{w}$ drodze do wieczności:

Щедро дни и ночи разметало время [...]

И теперь - в преддверьи - где-то на пороге -

Я стою с тяжелой ношей пустоты.

Żyć znaczy dla poetki znajdować się pomiędzy tymi dwoma punktami, „nie być ani tu, ani tam”, sytuować się ,poza zwyczajnymi ograniczeniami i ładem”, podążać do nowego stanu (Kowalski 23). W płaszczyźnie fabularnej takie konceptualizowanie świata i własnego w nim miejsca wyraża się w scenach pożegnania i powitania, do których poetka ma zauważalną predylekcję. Często czyni je osią sytuacji lirycznej wierszy, podkreślając - poprzez dobór komponentów przestrzennych - semantykę tymczasowości, zmienności ludzkiego losu. Do rozstania lub ponownego spotkania bohaterów lirycznych dochodzi zazwyczaj na progu domu, na ganku, na dworcu lub w porcie - a więc w ,miejscach paradoksalnych” (Eliade 64), naruszających ciągłość przestrzenną, oddzielających i zarazem łączących jej odmiennie nacechowane warianty i narzucany przez nie zmieniający się status człowieka (dom - poza domem, prywatne - publiczne, tu - tam, znane - nieznane, swoje - obce). Bohaterowie wierszy Lachman na ogół wyruszają w drogę lub zmierzają do jej kresu (w wariancie pasywnym: żegnają podróżnika bądź czekają na jego powrót, jak ma to miejsce m.in. w cyklu Вариации на темy). W taki czy inny sposób są w podróży: dosłownej, metaforycznej (wspomnienie, sen) oraz alegorycznej (życie).

Motyw peregrinatio vitae należy do kluczowych w omawianej poezji, szczególnie w drugim tomie wierszy, opublikowanym cztery lata przed śmiercią poetki, zawierającym wiersze o tematyce egzystencjalnej. Odpowiada mu szczególny status podmiotu lirycznego, naznaczonego piętnem nomadyzmu. Bywa on turystą, piechurem, wędrowcem, spacerowiczem lub tułaczem, nade wszystko jednak jest pielgrzymem, homo viator przemierzającym drogi życia. Istnienie człowieka, na które poetka stara się patrzeć sub specie aeternitatis, to trudna, pełna cierpienia, ale i fascynująca wyprawa przez przestrzenie fizyczne i mentalne, geograficzne i duchowe. Ich doświadczanie jest wartością samą w sobie, stanowi o sensie i celu ludzkiego bytu.

\section{Bibliografia}

Adamowski, Jan, Katarzyna Smyk, red. Droga w języku i kulturze. Analizy antropologiczne. Lublin, Wydawnictwo Uniwersytetu Marii Curie-Skłodowskiej, 2011.

Aleksandrov, Evgenij, Russkie v Severnoj Amerike. Biografičeskij slovar'. Hèmden-San FranciscoSankt Petersburg, Kongress Russkich Amerikancev, 2005. 
Bugaeva, Lûbov'. „Mifologiâ èmigracii: geopolitika i poètika”. Ent-Grenzen. Intellektuelle Emigration in der russischen Kultur des 20 Jahrhundrets. Red. Lyubov Bugaeva, Eva Hausbacher, Frankfurt am Main, Peter Lang, 2006, s. 51-71.

Cassirer, Ernst. Esej o człowieku. Wstęp do filozofii kultury. Przeł. Anna Staniewska. Przedmowa Bogdan Suchodolski. Warszawa, Czytelnik, 1971.

Cieśla-Korytowska, Maria, Olga Płaszczewska, red. Dziedzictwo Odyseusza. Podróż, obcość i tożsamość, identyfikacja, przestrzeń. Kraków, Universitas, 2007.

Cioran, Emil. „O zaletach wygnania”. Przeł. Krzysztof Zabłocki. Literatura na Świecie, 11, 1990, s. $222-226$.

Dobieszewski, Janusz. „Filozoficzność emigracji”. Studia Rossica VII: W kraju i na obczyźnie. Literatura rosyjska XX w. Red. Wiktor Skrunda. Warszawa, Wydawnictwo Studia Rossica, 1999, s. $27-39$.

Głowiński, Michał. „Przestrzenne tematy i wariacje”. Przestrzeń i literatura: tom poświęcony VIII kongresowi slawistów. Red. Michał Głowiński, Aleksandra Okopień-Sławińska. Wrocław, Zakład Narodowy im. Ossolińskich, 1978, s. 79-97.

Eliade, Mircea. Sacrum, mit, historia. Wybór esejów. Przeł. Anna Tatarkiewicz. Warszawa, PIW, 1970.

Fedoruk, Oleksandr. „Lirične divo Gizeli Lahman”. Gizela Lahman. Vibrani poezii/Gizella Sigizmundovna Lahman. Izbrannaâ poèziâ. Kiev, Triumf, 1997, s. 7-34. Web. 29.09.2020. http:// ju.org.ua/ru/literature/749.html.

Kočubej, Ûrij. „Dunovenie Serebrânogo veka (Vstupitel'noe slovo)”. Gizela Lahman. Vibrani poezii/ Gizella Sigizmundovna Lahman. Izbrannaâ poèziâ. Kiev, Triumf, 1997, s. 4-6. Web. 29.09.2020. http://ju.org.ua/ru/literature/749.html.

Kovaldži, Kiril, red. „My žili togda na planete drugoj...”. Antologiâ poèzii russkogo zarubež'â. 1920-1990 (pervaâ i vtoraâ volna). Sostavlenie E.V. Vitkovskogo. Biografičeskie spravki i kommentarii G. I. Mosešvili, Kn. 2. Moskva, Moskovskij rabočij, 1994.

Kowalski, Piotr. Odyseje nasze byle jakie. Droga, przestrzeń i podróżowanie w kulturze współczesnej. Wrocław, Wrocławskie Wydawnictwo Naukowe ATLA 2, 2001.

Krejd, Vadim. „Lahman Gizella Sigizmundovna (1895-1969)”. Novyj istoričeskij vestnik, 3, 2001, s. 190-191. Web. 07.07.2020. http://www.nivestnik.ru/2001_3/14.shtml.

Krejd, Vadim, red. „Vernut'sâ v Rossiû stihami...”. 200 poètov èmigracii. Antologiâ. Moskva, Izdatel'stvo Respublika, 1995.

Lahman, Gizela. Vibrani poezii/Gizella Sigizmundovna Lahman. Izbrannaâ poèziâ. Kiev, Triumf, 1997. Web. 29.09.2020. http://ju.org.ua/ru/literature/749.html.

Leving, Ûrij. „«Ahmatova russkoj èmigracii» - Gizella Lahman”. Novoe literaturnoe obozrenie, 5, 2006, s. 164-173. Web. 13.07.2020. https://magazines.gorky.media/nlo/2006/5/ahmatovarusskoj-emigraczii-gizella-lahman.html.

Ligęza, Wojciech. „Poeta emigracyjny: role i wyobrażenia”. Literatura a wyobcowanie. Red. Jerzy Święch. Lublin, LTN, 1990, s. 79-91.

Łotman, Jurij. „Zagadnienia przestrzeni artystycznej w prozie Gogola”. Przeł. Jerzy Faryno. Semiotyka kultury. Wybór i oprac. Elżbieta Janus, Maria Renata Mayenowa. Warszawa, PIW, 1977, s. 213-265.

Mandelsztam, Osip. Stowo i kultura. Przeł. Ryszard Przybylski. Warszawa, Czytelnik, 1972.

Miłosz, Czesław. Noty o wygnaniu. Web. 06.08.2020. http://biblioteka.teatrnn.pl/dlibra/ Content/31458/Noty_o_wygnaniu.pdf.

Ndiaye, Iwona Anna. Hipertrofia tęsknoty za utraconym domem w poezji emigrantów rosyjskich „pierwszej fali”. Olsztyn, Wydawnictwo Uniwersytetu Warmińsko-Mazurskiego w Olsztynie, 2008. 
Ndiaye, Iwona Anna, red. Poetycka Atlantyda. Antologia liryki kobiecej „pierwszej fali” emigracji rosyjskiej. Olsztyn, Wydawnictwo Uniwersytetu Warmińsko-Mazurskiego w Olsztynie, 2006.

Porębski, Mieczysław. „O wielości przestrzeni”. Przestrzeń i literatura: tom poświęcony VIII kongresowi slawistów. Red. Michał Głowiński, Aleksandra Okopień-Sławińska. Wrocław, Zakład Narodowy im. Ossolińskich, 1978, s. 23-33.

Russkaâ poèziâ Kitaâ. Antologiâ. Sost. Vadim Krejd, Olga Bakič. Moskva, Vremâ, 2001. Web. 18.09.2020. https://achiqkitab.aztc.gov.az/Books/Read/2495/Russkaya-poeziya-Kitaya-Antologiya.

Sławiński, Janusz. Dzieło - język - tradycja. Warszawa, PWN, 1974.

Słownik języka polskiego. Web. 05.08.2020. https://sjp.pwn.pl/slowniki/emigracja.html.

Time, Galina. „Izgnanie kak putešestvie: russkij vzglâd Drugogo (1920-e gody)”. Beglye vzglâdy. Novoe pročtenie russkih travelogov pervoj treti XX veka. Sbornik statej. Red. Vol'fgang Stefan Kissel'. Przeł. Galina A. Time. Moskva, Novoe literaturnoe obozrenie, 2010.

Tuan, Yi-Fu. Przestrzeń i miejsce. Przeł. Agnieszka Morawińska. Warszawa, PIW, 1987.

Wallis, Aleksander. Socjologia przestrzeni. Wybór i oprac. Elżbieta Grabska-Wallis, Maria Oficerska. Warszawa, Niezależna Oficyna Wydawnicza, 1990.

Wittlin, Józef. „Blaski i nędze wygnania”. Orfeusz w piekle XX wieku. Kraków, Wydawnictwo Literackie, 2000, s. 153-168.

Wyskiel, Wojciech. „Wprowadzenie do tematu: literatura i emigracja”. Pisarz na obczyźnie. Red. Tadeusz Bujnicki, Wojciech Wyskiel. Wrocław-Warszawa-Kraków-Lódź, Zakład Narodowy im. Ossolińskich, 1985, s. 7-52. 